\title{
Modified enzyme multiplied immunoassay technique of methotrexate assay to improve sensitivity and reduce cost
}

\author{
Xiaoping Shi ${ }^{1+}$, Hui Gao ${ }^{2 \dagger}$, Zhong $\mathrm{Li}^{1 *} \mathbb{D}$, Jinghua $\mathrm{Li}^{1}$, Yang Liu', Lujuan $\mathrm{Li}^{1}$ and Qi Zhang
}

\begin{abstract}
Background: Methotrexate is an important component in many chemotherapy protocols. The blood concentration of Methotrexate is used to determine the regimen of folinic acid. However, the lower limit of Siemens assay kit is $0.30 \mu \mathrm{mol} / \mathrm{L}$ in China. This study extended the limit from 0.3 to $0.05 \mu \mathrm{mol} / \mathrm{L}$ and reduced the test cost by optimizing the parameters of Enzyme Multiplied Immunoassay Technique assay.

Methods: Parameters of Enzyme Multiplied Immunoassay Technique assay were modified to decrease the volume of reagents $A$ and $B$. Then a standard curve with a new custom set of calibrators was prepared to detect low concentration. Intra-day and inter-day imprecision were assessed by control material and samples. The linearity of the modified assay was verified by analyzing a range of quality controls with known concentration from 0.05 to $1.00 \mu \mathrm{mol} / \mathrm{L}$. At last, the same samples were tested by modified Enzyme Multiplied Immunoassay Technique assay and Liquid Chromatography-tandem Mass Spectrometry assay respectively. A simple linear regression was performed to verify the validity of the modified Enzyme Multiplied Immunoassay Technique assay.
\end{abstract}

Results: Intra-day and inter-day imprecision show good reproducibility at all levels $(0.05,0.12,0.43,0.82 \mu \mathrm{mol} / \mathrm{L})$. The linearity equation of modified assay was $y=0.9913 x+0.0046$, in which y was the mean of measured concentration and $x$ was the target concentration $\left(R^{2}=0.9994\right)$. In the range of $0.05-10.00 \mu \mathrm{mol} / \mathrm{L}$, correlation between the Modified assay and Liquid Chromatography-tandem Mass Spectrometry assay was significant $(r=0.9968)$. In the range of $0.30-10.00 \mu \mathrm{mol} / \mathrm{L}$, the correlation between modified and commercial assays was significant $(r=0.9987)$ as well.

Conclusions: The modified assay enhanced the sensitivity of Siemens VIVA-E to $0.05 \mu \mathrm{mol} / \mathrm{L}$. In addition, the test number of a reagent Kit increased from 140 to 210. This means the cost of detection was reduced about 30\%.

Keywords: Methotrexate, Enzyme multiplied immunoassay technique, Sensitivity, Cost reduction

\section{Background}

Methotrexate (MTX) has been used worldwide to treat a broad spectrum of diseases, such as leukemia, nonHodgkin's lymphoma, osteosarcoma and other malignancies. When high dose of MTX (HDMTX) is administered intravenously and followed by rescue with folinic acid, it is crucial to monitor the blood concentration of MTX at the fixed time points to determine the optimal dose and regimen of folinic acid. In general, folinic acid rescue is continued until MTX concentration fall below

\footnotetext{
* Correspondence: Lzong159@139.com

†Xiaoping Shi and Hui Gao contributed equally to this work.

'Pharmacy Department of Dalian Children's Hospital, No.154, Zhongshan

Road, Dalian City 116012, Xigang District, China

Full list of author information is available at the end of the article
}

$0.10 \mu \mathrm{mol} / \mathrm{L}$ at $72 \mathrm{~h}$ or below $0.05 \mu \mathrm{mol} / \mathrm{L}$ at $96 \mathrm{~h}$ after MTX administration [1]. Siemens VIVA-E instrument provides an effective assay for monitoring MTX. However, it has two deficiencies. Firstly, the lower limit of this assay is just $0.30 \mu \mathrm{mol} / \mathrm{L}$, which is insufficient to meet the diagnostic criterion to terminate folinic acid rescue. Secondly, the cost of MTX assay on Viva-E is so high that hospital's laboratory could not afford routine test. There were many articles about how to enhance the sensitivity of Enzyme Multiplied Immunoassay Technique (EMIT) assay, but the cost of MTX detection has been ignored [2,3]. In this study, not only the lower limit of quantitation decreased from $0.30 \mu \mathrm{mol} / \mathrm{L}$ to $0.05 \mu \mathrm{mol} / \mathrm{L}$, but also the cost of detection was reduced about $30 \%$. 


\section{Methods}

\section{Instrument and reagents}

The instrument for MTX detection was Siemens VIVA-E which allows for parameter customization through the availability of open channel. MTX reagents and calibrators were purchased from Siemens (6L119UL).

Three levels of Quality control (QC) material were purchased from Bio-Rad (Irvine, CA), an additional custom QC material at $0.05 \mu \mathrm{mol} / \mathrm{L}$ from Aladdin (Shanghai, China).

MTX method comparison was performed by analyzing the same samples using Liquid Chromatography-tandem Mass Spectrometry (LC-MS/MS) assay (LC-20 AD Liquid Chromatography, and AB SCIEX QTRAP ${ }^{\circledR} 4500$ Mass Spectrometers).

\section{Specimens}

The test samples were obtained from the hematological ward of Dalian children's hospital. Some tested samples and MTX-free icteric plasma samples were collected for studying on triglyceride and bilirubin interference. There was no intervention in the treatment of patients, and none of patient's individual information was mentioned.

\section{Reagent preparation}

The Siemens Reagent Kit contains Antibody/Substrate Reagent A, Enzyme Reagent B, Emit Drug Assay Buffer Concentrate, and Emit Methotrexate Calibrators. Reagent $\mathrm{A}$ and $\mathrm{B}$ were reconstituted with $3.0 \mathrm{~mL}$ deionized water, mixed by gentle swirling, and equilibrated at room temperature for $1 \mathrm{~h}$. MTX buffer concentrate was mixed with deionized water $(1: 15 \mathrm{v} / \mathrm{v})$. Working solution of reagent $\mathrm{A}$ and $\mathrm{B}$ was prepared by diluting stock solutions $1: 9 \mathrm{v} / \mathrm{v}$ with buffer solution.

Some calibrators $(0,0.20,0.50,1.00 \mu \mathrm{mol} / \mathrm{L})$ were reconstituted to indicated concentration with $1.0 \mathrm{~mL}$ of deionized water according to the manufacturer's instructions, other calibrators 1.50 and $2.00 \mu \mathrm{mol} / \mathrm{L}$ were reconstituted to $1.00 \mu \mathrm{mol} / \mathrm{L}$ with 1.50 and $2.00 \mathrm{~mL}$ deionized water respectively. Then the $0.20 \mu \mathrm{mol} / \mathrm{L}$ calibrator was diluted into $0.05 \mu \mathrm{mol} / \mathrm{L}$, and the $1.00 \mu \mathrm{mol} / \mathrm{L}$ was diluted into 0.10 and $0.25 \mu \mathrm{mol} / \mathrm{L}$. The new set of calibrators $(0,0.05$, $0.10,0.25,0.50$ and $1.00 \mu \mathrm{mol} / \mathrm{L})$ meet the requirements of modified calibrator curve.

\section{Programming the Viva-E instrument}

An open channel on the Viva-E was programmed to change volumes of reagents A \& B from $180 \mu \mathrm{L}$ to $110 \mu \mathrm{L}$ ( $110 \mu \mathrm{L}$ is the lower limit of Viva-E for MTX reagents). A six-point calibration curve was programmed with modified cubic spline regression. The six calibrators provided by the Kit were $0,0.20,0.50,1.00,1.50$ and $2.00 \mu \mathrm{mol} / \mathrm{L}$. When the volumes of reagents A and B were decreased, they were not sufficient to react with samples more than
$1 \mu \mathrm{mol} / \mathrm{L}$. As a result, the new calibrator set of modified EMIT assay was changed to $0,0.05,0.10,0.25,0.50$, $1.00 \mu \mathrm{mol} / \mathrm{L}$ within a range of 0.05 to $1.00 \mu \mathrm{mol} / \mathrm{L}$.

According to the instruction of the commercial kit, the samples of concentration more than $1.00 \mu \mathrm{mol} / \mathrm{L}$ should be diluted into the scope of calibration curve (0.05$1.00 \mu \mathrm{mol} / \mathrm{L})$ using dilution factor of 10,100 or 1000 .

\section{Limit of blank, limit of detection, limit of quantitation}

Limit of blank (LOB), limit of detection (LOD), limit of quantitation (LOQ) were determined according to CLSI EP17-A [4, 5]. LOB was assayed using six samples (S1S6, 10 replicates over 10 days): $\mathrm{S} 1$ and $\mathrm{S} 2$ were zero calibrators from two different calibrator lots, S3 and S4 were diluent, S5 and S6 were blank plasma. LOD was assayed with 5 low-level sample pools ranging from the LOB to four times the LOB (12 replicates over 12 days). LOB and LOD were determined by two lots of reagents. According to the clinical requirements, the goal for total error was set to $20 \%$. The test results of LOD study was used to estimate the bias and imprecision for each level of the analyte. Then these data were combined to estimate the total error at each level and determine the limit of quantitation (LOQ).

\section{Intra-day and inter-day imprecision}

Intra-day $(n=10)$ imprecision of modified assay was evaluated by one level of control materials $(0.05 \mu \mathrm{mol} / \mathrm{L})$ and three levels of patient samples $(0.12,0.43,0.82 \mu \mathrm{mol} / \mathrm{L})$. At each level, 10 replicates were carried out. Inter-day $(n=25)$ imprecision was tested at these 4 levels in 5 consecutive days, and 5 replicates for each level. All the samples were obtained from different patients. The measured results were plotted against the expected values.

\section{Linearity}

The linearity was verified by diluting the quality control of $2.00 \mu \mathrm{mol} / \mathrm{L}$ (hc) with buffer (c0) at the following ratios: $1 \mathrm{hc}+1 \mathrm{c} 0 \quad(1.00 \mu \mathrm{mol} / \mathrm{L}), 2 \mathrm{hc}+3 \mathrm{c} 0 \quad(0.80 \mu \mathrm{mol} / \mathrm{L})$, $1 \mathrm{hc}+2 \mathrm{co}(0.67 \mu \mathrm{mol} / \mathrm{L}), 1 \mathrm{hc}+3 \mathrm{co}(0.50 \mu \mathrm{mol} / \mathrm{L}), 1 \mathrm{hc}+$ 5 co $(0.33 \mu \mathrm{mol} / \mathrm{L}), 1 \mathrm{hc}+9 \mathrm{co}(0.20 \mu \mathrm{mol} / \mathrm{L}), 1 \mathrm{hc}+19 \mathrm{co}$ $(0.10 \mu \mathrm{mol} / \mathrm{L}), 1 \mathrm{hc}+39 \mathrm{co}(0.05 \mu \mathrm{mol} / \mathrm{L})$. Every dilution was analyzed three times, the linearity equation of modified assay was calculated based on the means of measured results and the expected values.

\begin{tabular}{llllll}
\multicolumn{6}{l}{ Table $\mathbf{1}$ Intra-day } \\
\hline Level & Target & Mean & SD & \%CV & \%Bias \\
\hline 1 & 0.05 & 0.050 & 0.004 & 9.43 & $<0.01$ \\
2 & 0.12 & 0.121 & 0.010 & 8.22 & $0.83 \%$ \\
3 & 0.43 & 0.428 & 0.021 & 5.02 & $-0.47 \%$ \\
4 & 0.82 & 0.817 & 0.026 & 3.22 & $-0.37 \%$ \\
\hline
\end{tabular}

$N=10$, Unit: $\mu \mathrm{mol} / \mathrm{L}$ 
Table 2 Inter-day Imprecision for Modified MTX Assay

\begin{tabular}{llllll}
\hline Level & Target & Mean & SD & \%CV & \%Bias \\
\hline 1 & 0.05 & 0.049 & 0.006 & 11.62 & $-1.60 \%$ \\
2 & 0.12 & 0.113 & 0.011 & 9.78 & $-5.67 \%$ \\
3 & 0.43 & 0.418 & 0.019 & 4.55 & $-2.88 \%$ \\
4 & 0.82 & 0.799 & 0.032 & 4.11 & $-2.59 \%$ \\
\hline
\end{tabular}

$N=25$, Unit: $\mu \mathrm{mol} / \mathrm{L}$

\section{The LC-MS/MS assay procedure}

The LC-MS/MS assay performed in this study is as follows. Diphenhydramine was used as the internal standard. Acetonitrile was used as the serum precipitant to eliminate albumin. A Hypersil ODS-BP C18 $(5 \mu \mathrm{m}$, $2.1 \times 150 \mathrm{~mm}$ ) column was used for LC separations. The mobile phase was $0.1 \%$ formic acid and acetonitrile. Gradient elution was performed at a flow rate of $0.5 \mathrm{~mL} / \mathrm{min}$ at $30^{\circ} \mathrm{C}$. The multiple reaction monitoring (MRM) mode was used to detecte MTX and diphenhydramine in electrospray ionization (ESI) source and positive ion scan mode. MTX was detected at $\mathrm{m} / \mathrm{z} 455.0 \rightarrow 308.1$, diphenhydramine was detected at $\mathrm{m} / \mathrm{z} 256.0 \rightarrow 167.0[6,7]$.

\section{Method comparison}

Seventy-nine samples were collected from acute lymphoblastic leukemia patients in Hematological Ward of Dalian Children's hospital. Every sample was tested using modified EMIT assay and LC-MS/MS assay respectively. The results were compared using simple linear regression analysis (MedCalc Statistical Software version 15.6.1). Another 45 samples were tested using modified EMIT assay and commercial EMIT assay for method comparison [8].

\section{Interference studies}

Triglyceride interference was assessed by preparing samples with Intralipid (20\% IV fat emulsion). The concentration of triglycerides in the samples was $1000 \mathrm{ng} / \mathrm{dL}$. Then Paired-T test was performed.

Bilirubin interference was simulated using some MTXfree icteric plasma samples with bilirubin concentration no less than $30 \mathrm{mg} / \mathrm{dL}$.

The interference from the structurally related metabolite 7-hydroxy-methotrexate was assessed by adding different levels of 7-hydroxy-methotrexate to the plasma samples, the concentration of MTX in those samples was 0.05
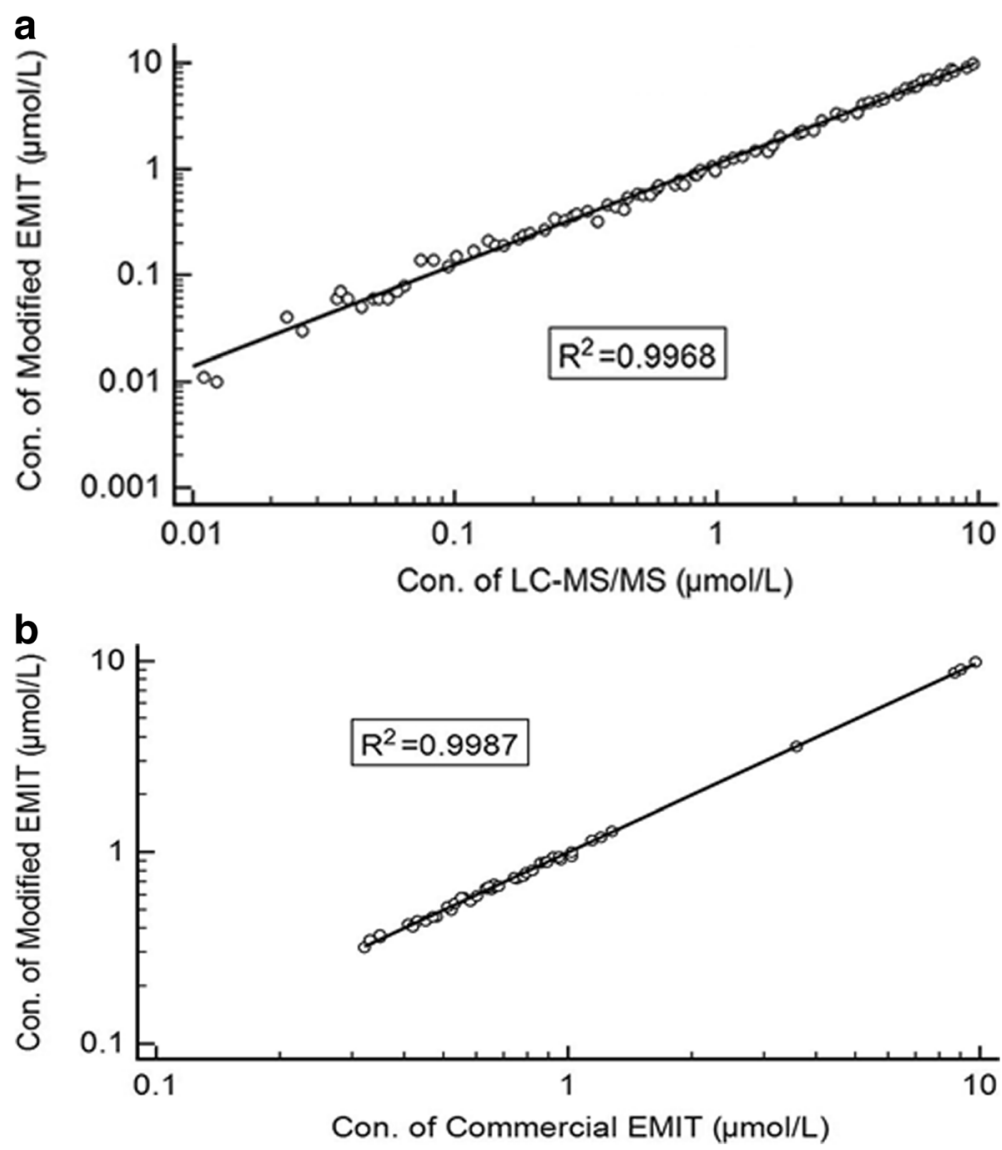

Fig. 1 a Method comparison between modified EMIT assay and LC-MS/MS assay in the range of $0.05-10.00 \mu \mathrm{mol} / \mathrm{L}$. (EMIT) $=1.0872(\mathrm{LC}-\mathrm{MS} / \mathrm{MS})+$ $0.0281, N=79, R^{2}=0.9968$. b. Method comparison between Modified assay and Commercial assay in the range of $0.30-10.00 \mu \mathrm{mol} / \mathrm{L}$. (Modified) $=$ 1.0080(Commercial)-0.0064, $N=45, R^{2}=0.9987$ 

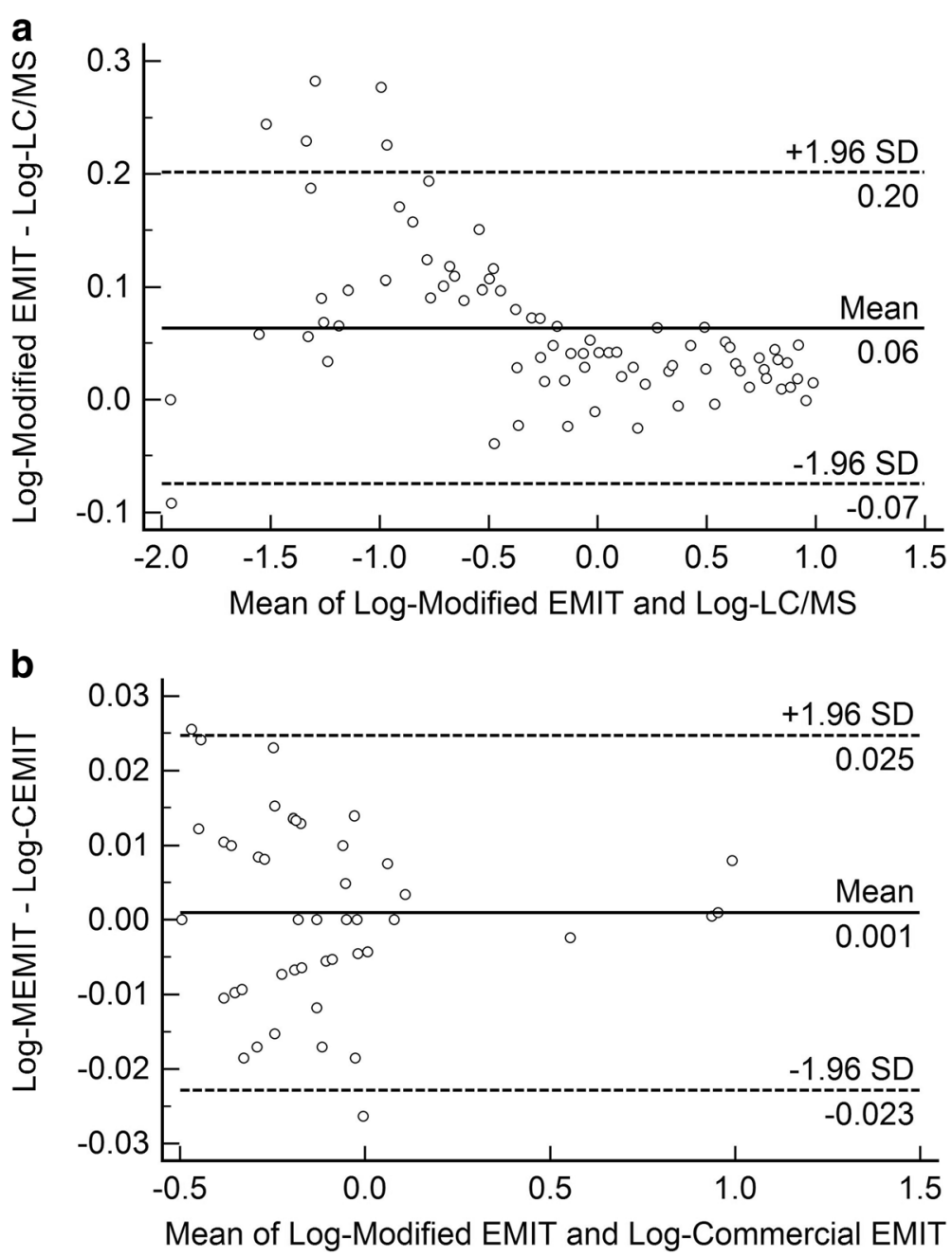

Fig. 2 a Bland-Altman plot of the differences ( $Y$-axis) and means (X-axis) of the logarithmic transformed values obtained from Modified EMIT and LC-MS/MS measurements $(n=79)$. b. Bland-Altman plot of the differences ( $Y$-axis) and means $(X$-axis) of the logarithmic transformed values obtained from Modified EMIT and Commercial EMIT measurements $(n=45)$

$\mu \mathrm{moL} / \mathrm{L}$. And the test results of current samples were compared with the results of original samples $[9,10]$.

\section{Results}

The LOB was found to be $0.0146 \mu \mathrm{mol} / \mathrm{L}$ and the LOD $0.0360 \mu \mathrm{mol} / \mathrm{L}$. The data of LOD suggested CV\% of pool measurements with concentration $0.0438 \mu \mathrm{mol} / \mathrm{L}$ was 9.82 , and the estimation of total error (19.67) was less than the goal for total error. According to Total Therapy Study XVI for Newly Diagnosed Patients with Acute Lymphoblastic Leukemia (ALL), $0.05 \mu \mathrm{moL} / \mathrm{L}$ could meet the clinical requirements. Thus, LOQ was set to $0.05 \mu \mathrm{moL} / \mathrm{L}$.

Intra-day imprecision (Table 1) was evaluated by withinrun and inter-day imprecision (Table 2) between days. Inter-day imprecision data were collected by assaying the 4 levels (one control material, and three patient samples) 25 times on five consecutive days. Intra-day and inter-day imprecision showed good reproducibility at all levels
$(0.05,0.12,0.43,0.82 \mu \mathrm{mol} / \mathrm{L})$. It shows that the assay is reproducible at the low end.

The analytical data for linearity was obtained from diluted quality control material with known concentration (1.00, 0.80, 0.67, 0.50, 0.33, 0.20, 0.10 and $0.05 \mu \mathrm{mol} / \mathrm{L})$. The linearity equation of modified assay was $y=0.9913 x$ +0.0046 , in which y was the mean of measured concentration and $x$ was the target concentration $\left(R^{2}=0.9994\right)$.

LC-MS/MS assay also showed good linearity within the range of $0.002-2.20 \mu \mathrm{mol} / \mathrm{L}(1-1000 \mathrm{ng} / \mathrm{mL})$. The linearity

Table 3 Interference Studies

\begin{tabular}{llll}
\hline Sample & Mean & Bias & \%Bias \\
\hline Blank & 0.56 & & \\
Triglyceride & 0.61 & 0.05 & 8.93 \\
Bilirubin & 0.52 & -0.04 & 7.14 \\
\hline
\end{tabular}

$N=5$, Unit: $\mu \mathrm{mol} / \mathrm{L}$ 
Table 4 Interference Studies of Structurally Related Compound

\begin{tabular}{lllll}
\hline $\begin{array}{l}\text { Estimated MTX } \\
(\mu \mathrm{moL} / \mathrm{L})\end{array}$ & $\begin{array}{l}\text { Estimated 7-hydroxy- } \\
\text { methotrexate }(\mu \mathrm{moL} / \mathrm{L})\end{array}$ & $\begin{array}{l}\text { Measured MTX } \\
(n=5)(\mu \mathrm{moL} / \mathrm{L})\end{array}$ & Bias & \%Bias \\
\hline 0.05 & 0.00 & 0.049 & & \\
& 0.05 & 0.506 & 0.0008 & 1.61 \\
& 0.50 & 0.522 & 0.0024 & 4.82 \\
& 1.00 & 0.543 & 0.0045 & 9.04 \\
& 2.50 & 0.566 & 0.0068 & 13.65 \\
& 5.00 & 0.597 & 0.0099 & 19.88 \\
& & & & \\
& & & & \\
& & & & \\
& & & &
\end{tabular}

equation was $\mathrm{Y}=0.0955 \mathrm{X}-0.026, \mathrm{R}^{2}=0.9971$. The intraday and inter-day RSD were both less than $9.0 \%$. The average recovery of methotrexate was $95.86-112.31 \%$.

Method comparison was performed by comparing the results of modified EMIT assay with the results from LC-MS/ MS assay and commercial EMIT assay respectively (Fig. 1a \& 1b). For modified EMIT, the samples with concentration from 1.00 to $10.00 \mu \mathrm{mol} / \mathrm{L}$ should be diluted 10 times into the scope of calibration curve $(0.05-1.00 \mu \mathrm{mol} / \mathrm{L})$. In the range of $0.05-10.00 \mu \mathrm{mol} / \mathrm{L}$, correlation between the Modified assay and LC-MS/MS was significant $(r=0.9968)$. In the range of $0.30-10.00 \mu \mathrm{mol} / \mathrm{L}$, the correlation between modified and commercial assays was significant $(r=0.9987)$. As Fig. 2a and Fig. 2b shown, there was no significant difference between the results of LC-MS/MS assay and modified assay or between the results of modified and commercial assays.

Triglyceride and Bilirubin interference were simulated (Table 3), All Bias of three groups were less than 10\%, which is an acceptable cutoff.

The interference of structurally related metabolite 7-hydroxy-methotrexate was also simulated (Table 4). The ratio of MTX to 7-hydroxy-methotrexate in the test samples ranged from 1:1 to 1:100. All Bias were less than $20 \%$.
There was no obvious difference of dilution frequency between modified and commercial assays. The information of 202 samples were collected. Among them, 57 samples were collected at $23 \mathrm{~h}$ from the start of the infusion, they were more than $10.00 \mu \mathrm{mol} / \mathrm{L}$ and no need to be diluted in both two assays. The other 145 samples were collected more than $44 \mathrm{~h}$, they were less than $2.00 \mu \mathrm{mol} / \mathrm{L}$. Figure 3 shows a distribution plot of the 145 points, 141 points are under $1.00 \mu \mathrm{mol} / \mathrm{L}, 4$ points are between $1.00-2.00 \mu \mathrm{mol} / \mathrm{L}$. That means only 4 of the 202 samples need additional dilution to make their concentrations fall in the calibration range. Moreover, the test number of Reagent Kit increased from 140 to 210. As a result, the cost of detection was reduced about $30 \%$.

\section{Discussion}

There are two methods that can increase the sensitivity of EMIT MTX assay. The one is to increase the volume of samples. That has been reported. The other is to decrease the volume of reagents A and B. Both methods aim to increase the concentration of MTX in mixed solution for test. In this study, the volumes of reagents A \& B were decreased from $180 \mu \mathrm{L}$ to $110 \mu \mathrm{L}$, this procedure reduces the consumption of reagents and lowered the cost of the assay, so far it has not been issued by any thesis. Then the calibration set was modified by adding three low concentrations calibrators $0.05,0.10,0.25 \mu \mathrm{mol} / \mathrm{L}$ and removing 3 calibrators $0.20,1.50,2.00 \mu \mathrm{mol} / \mathrm{L}$. The added calibrators were prepared by diluting manufacturer calibrators. As a result, an accurate assay with a measuring range of $0.05-1.00 \mu \mathrm{mol} / \mathrm{L}$ was established.

The comparison graph of modified EMIT and LC-MS/ MS showed that the results of EMIT has a positive bias (Fig. 2), which is consistent with the published studies [11].

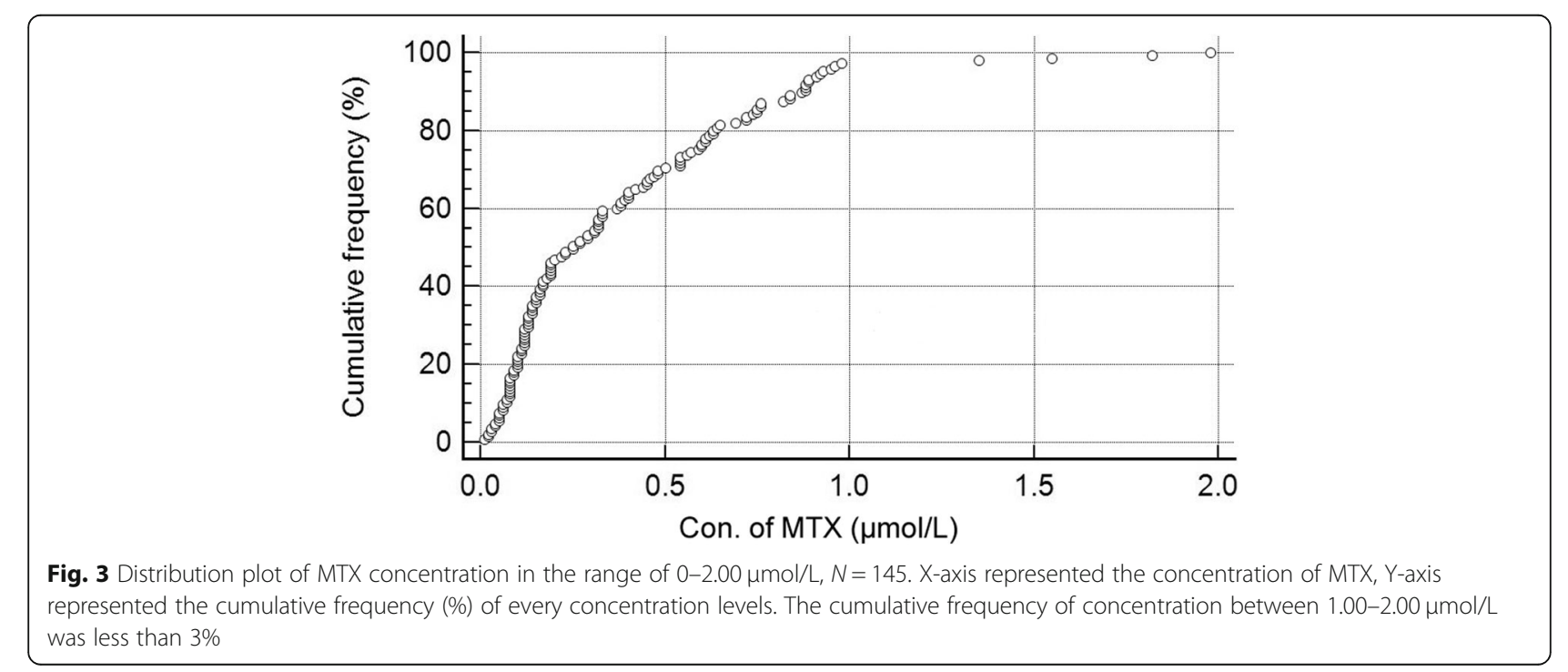


There were two possible influence factors, albumin-bound MTX and metabolite(s) of MTX found in plasma. However, the extraction efficiency of MTX in LC-MS/MS was 95.86\% 112.31\%, which means the acetonitrile precipitation is an effective approach to dissociate the bound drug from the protein. For this reason, bound MTX would not be the main factor that resulted in significant difference between the two methods. Maybe the metabolite of MTX caused the difference of the two methods.

In the following study, we aim to analyze the result of therapeutic MTX monitoring from childhood ALL patients in our hospital. Since the detection range of MTX extended from $0.3 \mu \mathrm{mol} / \mathrm{L}$ to $0.05 \mu \mathrm{mol} / \mathrm{L}$, it enables us to establish a model for predicting MTX toxicity and delayed clearance, as well as to provide an accurate indicator for folinic acid rescue. This modified EMIT assay not just guarantees the rational and safety use of MTX, it also provides a more efficient way to conduct relative pharmaceutical or clinical studies.

\section{Conclusion}

MTX has been used worldwide to treat childhood ALL in many protocols, it is necessary to detect the blood concentration of MTX at low level less than $0.3 \mu \mathrm{mol} / \mathrm{L}$. This study modified the EMIT MTX assay on Siemens VIVA-E instrument to enhance the sensitivity from $0.3 \mu \mathrm{mol} / \mathrm{L}$ to $0.05 \mu \mathrm{mol} / \mathrm{L}$. At the same time, the test number of a reagent Kit increased from 140 to 210, which means the cost of detection was reduced about $30 \%$. The precision and correlation data indicate there is no difference between modified method and commercial method. The modified method could be used in routine clinical practice for monitoring MTX concentration at the level less than $0.3 \mu \mathrm{mol} /$ L.

\section{Abbreviations \\ ALL: Acute Lymphoblastic Leukemia; CLSI: Clinical and Laboratory Standards Institute; EMIT: Enzyme Multiplied Immunoassay Technique; ESI: Electrospray Ionization; HDMTX: High Dose Methotrexate; LC-MS/MS: Liquid Chromatography-tandem Mass Spectrometry; LOB: Limit of Blank; LOD: Limit of Detection; LOQ: Limit of Quantitation; MRM: Multiple Reaction Monitoring; MTX: Methotrexate; QC: Quality Control}

\section{Acknowledgements}

The authors would like to thank all the colleagues who participate in this project.

\section{Funding}

This work was supported by grants from Dalian Municipality Medical Research Project (No.1611056). It is a government fund without any commercial object. The whole grants were spent on reagents and quality control material used in the experiment.

\section{Availability of data and materials}

The datasets generated and analyzed during the current study are not publicly available due the confidentiality agreement between our hospital and Chinese Children's Leukemia Group (CCLG). But these are available from the corresponding author on reasonable request.

\section{Authors' contributions}

$X S, H G$, and ZL conceived of the presented idea and developed the study design. HG collected all samples. XS measured all the samples with modified method and recorded the results. YL measured all the samples with commercial method and recorded the results. LL measured all the samples with LC-MS/MS and recorded the results. ZL and QZ performed the analytic calculations and compared values obtained from the three methods. QZ verified the analytical methods and calibrated all instrumental errors. $\mathrm{HG}$ and $\mathrm{J}$ contributed to the interpretation of the results. $\mathrm{ZL}$ and $\mathrm{JL}$ drafted and submitted the manuscript. XS and HG made the same contribution, so they are the co-first authors. ZL is the corresponding author. All authors discussed the results and contributed to the final manuscript. All authors read and approved the final manuscript.

\section{Ethics approval and consent to participate}

According to No.11 Decree, "Ethical Review of Biomedical Research involving Human Beings", issued by The State Health and Family Planning Commission of the People's Republic of China on October 12th, 2016, we just collected test values passively and did not intervene in medical procedure and disclose any individual information, the consent of participate could be waived. We obtained consent waiver from Ethics Committee of Dalian Children's hospital.

\section{Consent for publication}

This manuscript does not contain data from any individual person, the consent for publication is not applicable.

\section{Competing interests}

The authors declare that they have no competing interest.

\section{Publisher's Note}

Springer Nature remains neutral with regard to jurisdictional claims in published maps and institutional affiliations.

\section{Author details}

'Pharmacy Department of Dalian Children's Hospital, No.154, Zhongshan Road, Dalian City 116012, Xigang District, China. ${ }^{2}$ Hematology Ward of Dalian Children's Hospital, No.154, Zhongshan Road, Dalian City 116012, Xigang District, China.

Received: 18 March 2018 Accepted: 27 December 2018

Published online: 09 January 2019

\section{References}

1. Soldin OP, Soldin SJ. Review: therapeutic drug monitoring in pediatrics. Ther Drug Monit. 2002;24:1-9.

2. Borgman MP, Hiemer MF, Molinelli AR, Ritchie JC, Jortani SA. Improved sensitivity for methotrexate analysis asing enzyme multiplied immunoassay technique on the Siemens Viva-E instrument. Ther Drug Monit. 2012;34:193-7.

3. Mendu DR, Chou PP, Soldin SJ. An improved application for the enzyme multipled immunoassay technique for caffeine, amikacin, and methotrexate assays on the Dade-Behring dimension RxL max clinical chemistry system. Ther Drug Monit. 2007;29:632-7.

4. Guidance for industry. In: Bioanalytical method validation. Food and Drug Administration. 2018. https://www.fda.gov/downloads/Drugs/Guidance/ ucm070107.pdf

5. Protocols for determination of limits of detection and limits of quantitation. In: CLSI standards documents. Clinical and laboratory standards institute. 2004. https://clsi.org/standards/products/method-evaluation/documents/ep17/

6. Bouquié R, Deslandes G, Bernáldez BN, Renaud C, Dailly E, Jolliet P. A fast LC-MS/ MS assay for methotrexate monitoring in plasma: validation, comparison to FPIA and application in the setting of carboxypeptidase therapy. Anal Methods. 2013:6:178-86.

7. Al-Ghobashy MA, Hassan SA, Abdelaziz DH, Elhosseiny NM, Sabry NA, Attia AS, et al. Development and validation of LC-MS/MS assay for the simultaneous determination of methotrexate, 6-mercaptopurine and its active metabolite 6-thioguanine in plasma of children with acute lymphoblastic leukemia: correlation with genetic polymorphism. J Chromatogr B. 2016;1038:188-94

8. Bouquié R, Grégoire M, Hernando H, Azoulay C, Dailly E, Monteil-Ganière C, et al. Evaluation of a methotrexate chemiluminescent microparticle 
immunoassay comparison to fluorescence polarization immunoassay and liquid chromatography-tandem mass spectrometry. Am J Clin Pathol. 2016;146(1):119-24.

9. Fotoohi K, Skärby T, Söderhäll S, Peterson C, Albertioni F. Interference of 7hydroxymethotrexate with the determination of methotrexate in plasma samples from children with acute lymphoblastic leukemia employing routine clinical assays. J Chromatogr B. 2005;817:139-44.

10. Guo P, Wang X, Liu L, Belinsky MG, Kruh GD, Gallo JM. Determination of methotrexate and its major metabolite 7-hydroxymethotrexate in mouse plasma and brain tissue by liquid chromatography-tandem mass spectrometry. J Pharm Biomed Anal. 2007:43:1789-95.

11. Guerriero E, Simon N, Nelken B, Baldeyrou B, Djobo B, Vasseur M, et al. Unexpected overestimation of methotrexate plasma concentrations: analysis of a single center pediatric population. Ther Drug Monit. 2014;36(4):499-504.

Ready to submit your research? Choose BMC and benefit from:

- fast, convenient online submission

- thorough peer review by experienced researchers in your field

- rapid publication on acceptance

- support for research data, including large and complex data types

- gold Open Access which fosters wider collaboration and increased citations

- maximum visibility for your research: over $100 \mathrm{M}$ website views per year

At $\mathrm{BMC}$, research is always in progress.

Learn more biomedcentral.com/submissions 